\title{
The Mighty Picturebook
}

\section{Providing a Plethora of Possibilities}

JUDI MORELLLON

$\mathrm{P}$ icturebooks are books in which both words and illustrations are essential to the story's meaning. . . . In a true picturebook, the illustrations are integral to the reader's experience of the book and the story would be diminished or confusing without the illustrations." ${ }^{1}$ Readers may agree with this definition, but that is not the end of the conversation. Picturebook readers continue to engage in discussions in the library world and children's literature field about the audiences for, formats of, and uses of picturebooks in the literacy lives of readers, listeners, and viewers.

\section{Young Audiences for Picturebooks}

Many picturebooks are created expressly for a young readership. Reading to babies from birth is a critical way to help a child's brain form the connections that support cognitive development. ${ }^{2}$ As the child grows, picturebooks offer ideal read-aloud experiences that develop familial bonds and literacy routines as well as a child's vocabulary, enjoyment of books, and readiness for schooling. ${ }^{3}$ Picturebooks are a cornerstone of PLA/ALSC's Every Child Ready to Read 2nd Edition program that provides youth librarians, early childhood specialists, preschool teachers, childcare providers, and others with researchbased practices that can help young children develop emergent reader skills.
Picturebook authors, illustrators, and designers can create books that maximize the impact of a page turn by building suspense and leaving clues to foreshadow the print and illustrations on the next page. Clever word play and other surprising elements in print and illustrations also stretch story listeners' independent cognitive abilities and engage them in enriching literacy experiences.

For example, an older sibling can model fluent reading while engaging her brother in interactive conversations related to the book's print and illustrations. Picturebooks and wordless picturebooks are ideal for dialogic reading in which the more proficient reader engages the child in making meaning by asking open-ended questions about the print and images. This process develops children's ability to express themselves orally and make personal meaning from the text.

\section{Word Count and Book Length}

A picturebook's word count or page length can be a factor for families that struggle to make time for a daily read-aloud or bedtime story. Many picturebook publishers have responded to today's family pressures by reducing the number of words in the text or by keeping to a strict thirty-two pages. Childcare providers and library-based storytime readers may also reach

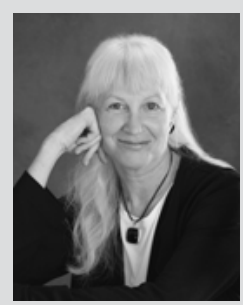

Judi Moreillon, MLS, PhD, is a Literacies and Libraries Consultant who served as a school librarian in preK-12 schools for thirteen years and as a librarian educator for twenty-one. She is the author of professional books on co-teaching reading comprehension strategies and has published two picturebooks, Read to Me/Vamos a leer (Starbright Books, 2004) and Ready and Waiting for You (Eerdmans Books for Young Readers, 2013). Visit her online at http:// storytrail.com. 


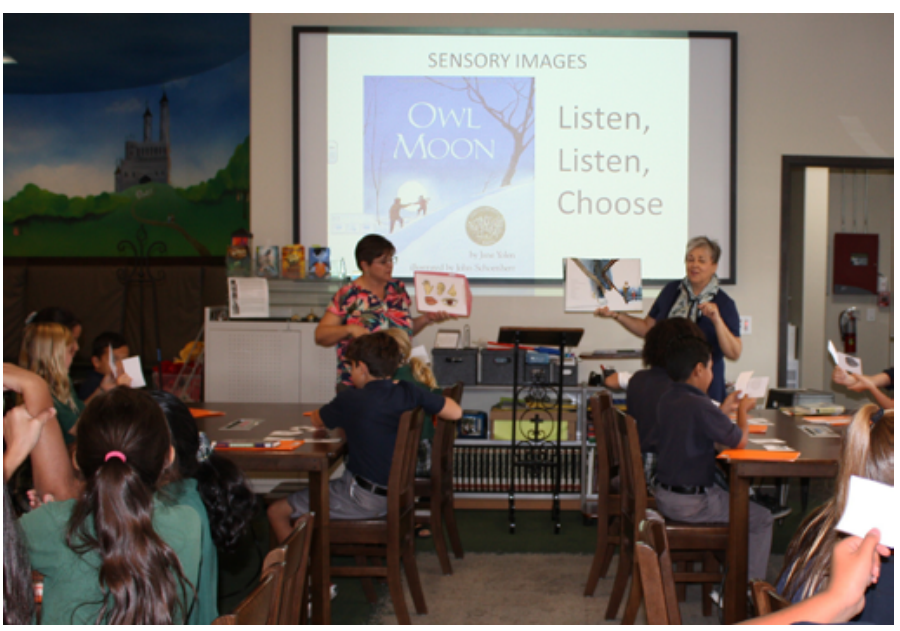

Teacher Kathi Stalzer and school librarian Debra LaPlante at Saints Simon and Jude Cathedral School in Phoenix, Arizona, coteaching a strategy lesson with fourth-grade students.

for shorter books. They may believe these selections will more easily hold the interest of an audience of young children who may have varied read-aloud experiences. However, "children's willingness to listen to stories grows with experience, which may result in a younger child who has been read to regularly having a much longer attention span than an older child with no story experience." ${ }^{4}$

Many parents and members of the general public think young children are the sole audience for picturebooks. Others realize there are multiple audiences for these texts. For example, researchers have studied how family literacy is portrayed in picturebooks and have found a tension between reading as a pleasurable parent-child experience and reading as parental "work"-another task in a long list of childrearing tasks. ${ }^{5}$ Picturebooks can also carry positive messages to the more proficient reader peer or adult reader that promote a love of books and reading. Reading picturebooks with young children can be a joyful family bonding experience that plays an important part in a child's development. Evaluating and choosing picturebooks to share with others requires a close examination of the book itself as well as knowledge of the book's intended audience and use.

\section{Visual Literacy}

The ability to make meaning from images is an essential twenty-first-century skill. Visual images dominate access to ideas and information via the screens that are all-pervasive in daily life. In addition, researchers estimate that people with typical vision process 80 to 85 percent of their perception, learning, cognition, and activities through vision. Many school librarians, reading specialists, and classroom teachers use picturebooks to teach visual literacy. "The illustrations in picturebooks often contain the details regarding setting, tone, and characters, and so children need to be able to use the visual elements as well as the literacy elements to create meaning and analyze a text." ${ }^{6}$
In a recent Children \& Libraries article, Jennifer Gibson wrote, "The visual sophistication of the author's/illustrator's work allows readers of all ages to interpret the story for themselves, whether orally, in writing, or in a different form of creative response." ${ }^{7}$ Readers can explore how the media and style illustrators choose impact readers' responses to the story or information. In addition to the illustrations, researchers Thomas Phinney and Lesley Colabucci suggest that the typography of a picturebook can support the print, enhance the tone of the story, accurately reflect the historical time period, or even detract from the book's themes or authenticity. ${ }^{8}$ Today's printing techniques support the creative use of typography to add visual interest as well as meaning to the story.

\section{Reading Comprehension and Inquiry Learning}

Picturebooks are also ideal for reading comprehension strategy lessons. Rather than select a passage from a longer work or use an excerpt found in a textbook, many educators use these complete, authentic texts and align them with content-area curriculum, such as science and social studies. They carefully select picturebooks that provide a complete set of story elements. Picturebooks that present a complete story arc with character development and thought-provoking themes can be ideal as mentor texts for strategy instruction.

In reading comprehension strategy instruction, educators use the mentor text to model the strategy for the learners. Educators think aloud while reading the text. They can share connections, questions, or confusions that go through their minds while they are engaged with a text. Picturebooks allow educators to model the strategy and give students opportunities to practice it with in a relatively short timeframe.

Informational picturebooks that present topical information in a narrative format support developing readers as they transition to books with text features such as tables of contents, headings and subheadings, glossaries, and indexes. Many of today's topical informational books are creatively illustrated. Although the books are not usually shelved with picturebooks, illustrators of these nonfiction texts do indeed use art to convey a large percentage of the information in these books.

Picturebooks can also be used as inquiry invitations for students of any age. Cyndi Giorgis and Lettie Albright note picturebook read-alouds can stimulate engaging discussions and critical thinking among secondary school readers and offer them an entry point into knowledge in content-area learning. ${ }^{9}$ Tom Bober notes a picturebook about women's suffrage such as Mara Rockliff's book Around America to Win the Vote: Two Suffragists, a Kitten, and 10,000 Miles can launch an investigation into the struggle for the Nineteenth Amendment. ${ }^{10}$ To deepen learning experience, this true story can be paired with primary sources, including historical newspaper articles found in databases. 


\section{Making Meaning as Discovery}

When students and educators enter into a dialogue with the text's author and illustrator, they can individually and collectively discover "truths" and develop theories about how the world works. The text questioning strategy called Question the Author, or QtA, is one way for readers to deepen their understandings of texts. ${ }^{11}$ This strategy is designed to increase readers' engagement with the text and activate their sense of discovery. With QtA, readers learn to deconstruct the writer's craft and share authority with the author and illustrator through questioning and interpreting text. When readers ask why an author uses a particular genre to convey ideas, they learn more about the choices writers make when they compose a text. When readers question authors' word choice and illustrators' images, they learn how picturebook creators use words and images to set a tone for the story and evoke a particular mood in the reader.

The meaningful connections readers make with texts position them to use these texts as a springboard for critical thinking, problem solving, and taking action. While making meaning is essential for developing reading proficiency, creative and thoughtful educators promote a sense of discovery in students' interactions with picturebook texts. When teaching comprehension strategies, educators engage readers as problem solvers who interrogate texts. Taking the role of detectives who "uncover" the clues the author or illustrator planted in the text is one way to challenge readers to dig deeper. Reading for meaning goes beyond a superficial level of extracting facts. It involves readers in making personal meaning and interpreting text; it is what strategic readers do.

Picturebooks offer exceptional opportunities for literacy learning and teaching as well as pleasure reading in preK-12 schools and libraries. When authors and illustrators create and publishers publish picturebooks with complete story arcs, compelling themes, intriguing illustrations, and rich information, parents and families, school and public librarians, classroom teachers and reading specialists can use these authentic texts in a plethora of ways. Those involved in creating picturebooks can further the impact of this literary art form by authoring, designing, and publishing picturebooks that reach multiple audiences and present exciting and varied formats to expand the uses and roles of picturebooks in homes, schools, and libraries. ¿.

\section{References}

1. Kathy G. Short, Carol Lynch-Brown, and Carl M. Tomlinson, Essentials of Children's Literature, 8th ed. (Boston: Pearson, 2014): 50.

2. Virginia Buysse and Patricia Wesley, Evidence-Based Practice in the Early Childhood Field (Washington, DC: Zero to Three Press, 2016).

3. Dorothy Stoltz, Elaine M. Czarnecki, and Connie Wilson, Every Child Ready for School: Helping Adults Inspire Young Children to Learn (Chicago: ALA, 2013).

4. Short, Lynch-Brown, and Tomlinson, Essentials of Children's Literature, 51.

5. Elizabeth Bullen and Susan Nichols, "Dual Audiences, Double Pedagogies: Representing Family Literacy as Parental Work in Picturebooks," Children's Literature in Education 42, no. 3 (September 2011): 213-25.

6. Short, Lynch-Brown, and Tomlinson, Essentials of Children's Literature, 51.

7. Jennifer Gibson, "Text Optional: Visual Storytelling with Wordless Picturebooks," Children \& Libraries 14, no. 2 (Summer 2016): 3.

8. Thomas Phinney and Lesley Colabucci, "The Best Font for the Job: Typography in Caldecott Winners, 1990-2010," Children \& Libraries 8, no. 3 (Winter 2010): 17-26.

9. Cyndi Giorgis, "The Power of Reading Picturebooks Aloud to Secondary Students," Clearing House 73, no. 1 (September 1999): 51; Lettie K. Albright, "Bringing the Ice Maiden to Life: Engaging Adolescents in Learning through Picturebook Read-alouds in the Content Areas," Journal of Adolescent Literacy 45, no. 5 (2002): 418-28.

10. Tom Bober, "Picturebooks and Primary Sources: Exploring Voting and Elections," School Library Connection (AugustSeptember 2016): 11-13.

11. Isabel L. Beck et al., "Questioning the Author: A Yearlong Classroom Implementation to Engage Students with Text," Elementary School Journal 96, no. 5 (1996): 385-414. 